\title{
DEBT AND AGENCY CONFLICT IN INDONESIAN MANUFACTURING FIRMS
}

\section{Hendra Wijaya, Rr. Puruwita Wardani}

Department of Accounting Faculty of Business Widya Mandala Catholic University Surabaya Dinoyo 42-44, Surabaya, 60265, Indonesia

\begin{tabular}{|c|c|}
\hline \multirow[b]{2}{*}{$\begin{array}{l}\text { Keywords: } \\
\text { agency conflict, } \\
\text { debt, firm value, } \\
\text { investment } \\
\text { decision } \\
\text { JEL Classification: } \\
\text { G11, G32 }\end{array}$} & ABSTRACT \\
\hline & $\begin{array}{l}\text { Companies in Indonesia have shareholders who are not dispersed or in other words the } \\
\text { ownership is only held by one majority shareholder. This study examined the effects of } \\
\text { investment decision on the firm value and the debt moderation on the effects of invest- } \\
\text { ment decisions on firm value. Debt moderation was used to test the agency conflict of debt } \\
\text { use on investment decision. The company samples in this research were } 90 \text { companies. } \\
\text { This research was conducted by using panel data regression with moderation. This study } \\
\text { found that investment decision had a positive effect on firm value and the use of higher } \\
\text { debt could lower the positive effect of investment decision on firm value. }\end{array}$ \\
\hline & ABSTRAK \\
\hline $\begin{array}{l}\text { Kata Kunci: } \\
\text { keputusan investasi, } \\
\text { nilai perusahaan, } \\
\text { utang, konflik } \\
\text { keagenan }\end{array}$ & $\begin{array}{l}\text { Perusahaan di Indonesia memiliki pemegang saham yang tidak tersebar atau dengan kata lain } \\
\text { kepemilikan sahamnya hanya dipegang oleh satu pemegang saham mayoritas. Penelitian ini } \\
\text { menguji pengaruh keputusan investasi terhadap nilai perusahaan dan moderasi utang pada } \\
\text { pengaruh keputusan investasi terhadap nilai perusahaan. Moderasi utang digunakan untuk } \\
\text { menguji konflik keagenan penggunaan utang pada pengambilan keputusan investasi. Sampel } \\
\text { perusahaan pada penelitian ini sejumlah } 90 \text { perusahaan. Penelitian ini dilakukan dengan } \\
\text { menggunakan regresi data panel dengan moderasi. Penelitian ini menemukan bahwa keputusan } \\
\text { investasi berpengaruh positifterhadap nilai perusahaan dan penggunaan utang yang semakin } \\
\text { tinggi menurunkan pengaruh positifkeputusan investasi terhadap nilai perusahaan. }\end{array}$ \\
\hline
\end{tabular}




\section{Jurnal Keuangan dan Perbankan | KEUANGAN}

Vol. 21, No. 2, April 2017: 211-217

A shareholder of a company (principal) needs the help of a manager (agent) when the company owned greater. It is because the shareholder cannot manage alone his company, so he should delegate his authority in taking business decisions in the company. The conflict between the principal and the agent can occur when the manager does not take the decisions in align with the interests of shareholder or is more concerned with its own interests and harms the shareholder. One form of decision-making taken is an investment decision.

Investment decision is the decision to make assets for the company from the investment opportunities that have been identified previously. Investment decision is a decision that can affect the firm value which is as the shareholder's wealth as it reflects the business continuity and cash flow in the future. The supporting empirical evidence that investment decision positively affects the firm value is Del Brio et al. (2003) and Fenandar \& Raharja (2012). In contrast, the result showing that the investment decision negatively affects the firm value or in other words the investment decision taken is not aligned with shareholder interest was conducted by Chen et al. (2006). Kim et al. (2005) also shows that investment decision in large groups in Korea is overinvestment, so it inflicts the financial loss to the shareholder.

Agency conflict can be reduced by using debt. Jensen (1986) stated that the use of debt can reduce the agency conflict. It is because a manager is more careful in making investment decision since a manager has an obligation to return principal and interest arising from the use of debt. Mahadwartha \& Ismiyanti (2007) argue that failure of manager in paying off the obligation can affect his reputation and his career. Supporting empirical evidence to support that use of debt can reduce agency conflict is supported by Manawaduge et al. (2011) who found that debt had a positive effect on firm value. The same thing is also resulted from the researches conducted by Antwi et al.
(2012) and Chowdury \& Chowdury (2011).

Agency conflict has two types: type 1 and type 2 (Villalonga \& Amit, 2006). Agency conflict type 1 is an agency conflict between shareholders (principal) and the manager (agent), while the agency conflict of type 2 is between the majority shareholder (principal) and minority shareholder (principal) (Villalonga \& Amit, 2006). Indonesia is a country which shares ownership is largely held by one shareholder and a lot of top-level managers who are part of the shareholder. It causes the agency conflict between the majority and the minority ownership (Claessens et al., 2000). Such condition may lead to higher debt use to facilitate conflicts between majority ownership and minority ownership and creditors (Mahadwartha \& Ismiyanti, 2007). Fitri et al. (2017) show in her research that family ownership positively affects expropriation risk, so it indicates that agency conflict type 2 occurs in Indonesia.

Empirical evidences supporting that the use of the higher debt can lower the firm value is shown by Yuliana et al. (2016) who find that debt usage in various industries companies in Indonesia negatively affects firm value. Salim \& Yadaf (2012) find that debt use in companies in Malaysia negatively affects the firm value. Ruan et al . (2011) find that the use of debt in companies in China negatively affects the firm value. It is therefore very interesting to conduct research using the impact of debt use on the influence of investment decisions to firm value.

\section{HYPOTHESES DEVELOPMENT}

Investment decision is a process to determine the type of assets owned by the company (Gitman \& Zutter, 2012). Investment decision reflects the continuity of an enterprise, and investment decision that has added value is the investment decision that has greater revenue than the investment costs incurred (Myers, 1977). In addition Ambarish et al. (1987) argue that investment 
decision reflects the company's future cash flows generated. Del Brio et al. (2003) in his research find that investment decision has a positive effect on firm value. Fenandar \& Raharja (2012) in their research in Indonesia find that investment decision has a positive effect on firm value.

$\mathrm{H}_{1}$ : the investment decision has a positive effect on the firm value.

Claessens et al. (2000) argue that agency conflict between majority and minority ownership may occur because Indonesia is a country whose shareholding is mostly held by only one shareholder. In addition to showing that ownership of shares is held mostly by one shareholder, in Indonesia it also shows that the top managers of the company are part of the majority shareholder. Mahadwartha \& Ismiyanti (2007) argue that companies whose shareholders are not scattered and the top managers are part of the controlling shareholder, the use of debt can facilitate expropriation of minority shareholders and creditors.

$\mathrm{H}_{2}$ : debt negatively moderates the positive effect of investment decision on the firm value.

\section{METHOD}

This study examined the effect of investment decisions on firm value and also examined the moderation effect of debt on the influence of investment decision on firm value. The population in this study was a manufacturing company listed on Indonesia Stock Exchange (BEI) in 2004-2013. Samples were taken by using purposive sampling and obtained 90 companies as the final samples from total population of 141 . The sampling criteria of this research were the companies publishing the annual financial statements from January $1^{\text {st }}, 2005$ to December $31^{\text {st }}, 2013$. Also the companies had complete data used for this study. The sampling process is shown in Table 1.

The data in this study were got from Indonesian Stock Exchange (IDX) on www.idx.co.id. Data analysis technique used in this research was panel data regression. The equation of this study is as follows:

$$
\begin{aligned}
\mathrm{NPR}_{\mathrm{it}}= & \alpha+\beta_{1} \mathrm{INV}_{\mathrm{it}}+\beta_{2} \mathrm{UTG}_{\mathrm{it}}+\beta_{3} \mathrm{INV}^{*} \mathrm{UTG}_{\mathrm{it}} \\
& +\beta_{4} \mathrm{UKP}_{\mathrm{it}}+\beta_{5} \mathrm{PRT}_{\mathrm{it}}+\varepsilon_{\mathrm{it}}
\end{aligned}
$$

Note:

NPR : firm value

INV : investment decision

UTG : debt

UKP : firm size

PRT : profitability

The dependent variable of this study was firm value (NPR). NPR in this study was measured using natural logarithm of market capitalization obtained from multiplication of share price per sheet multiplied by the number of dispersed shares. The independent variable of this research was gross capital investment (INV). INV was the total investment of the company in the form of fixed assets and working capital compared to total assets. The moderation variable of this study was debt (UTG). UTG in this study was measured using debt ratio compared to total assets owned by the company. The control variables in this study were firm size (UKP) and profitability (PRT). UKP

Table 1. Sampling Process

\begin{tabular}{lr}
\hline \multicolumn{1}{c}{ Process } & Number \\
\hline Manufacturing companies listed on Indonesia Stock Exchange on December 31st, 2013 & 141 \\
Companies that do not have complete data to use in research & $(51)$ \\
Final samples & 90 \\
\hline
\end{tabular}


Table 2. Research Variable

\begin{tabular}{|c|c|c|}
\hline Variable & Measurement & Scale \\
\hline Firm Value $\left(\mathrm{NPR}_{\mathrm{t}}\right)$ & Ln (Market price per share ${ }_{t} \times$ Number of Outstanding Shares $t_{t}$ ) & Ratio \\
\hline $\begin{array}{l}\text { Investment Decision } \\
\left(\mathrm{INV}_{t}\right)\end{array}$ & 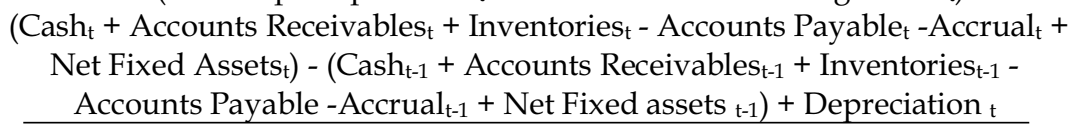 & Ratio \\
\hline Debt $\left(\mathrm{UTG}_{\mathrm{t}}\right)$ & $\begin{array}{c}\text { Total Assets } \\
\frac{\text { Debt }_{\mathrm{t}}}{\text { Total Assets }_{\mathrm{t}}}\end{array}$ & Ratio \\
\hline Firm size $\left(U K P_{t}\right)$ & Log (Total Assetst & Ratio \\
\hline \multirow[t]{2}{*}{ Profitability $\left(\mathrm{PRT}_{\mathrm{t}}\right)$} & Net Income ${ }_{t}$ & Ratio \\
\hline & Total Assets $_{\mathrm{t}}$ & \\
\hline
\end{tabular}

Table 3. Descriptive Statistics

\begin{tabular}{llllrrr}
\hline \multicolumn{1}{c}{ Variable } & Unit & N & Mean & Std. Dev. & \multicolumn{1}{c}{ Max } & Min \\
\hline Firm Value & Billion & 900 & 7.3843 & 28.8599 & 307.6750 & 0.0098 \\
Investment Decisions & Time & 900 & 0.0953 & 0.1457 & 1.4753 & -1.0156 \\
Debt & Time & 900 & 0.6072 & 0.5274 & 5.0252 & 0.0372 \\
Firm Size & Billion & 900 & 4.2050 & 13.9632 & 213.9940 & 0.0132 \\
Profitability & Time & 900 & 0.0538 & 0.1735 & 3.4747 & -1.4404 \\
\hline
\end{tabular}

in this study was measured using the logarithm of total assets, while PRT in this study was measured by using a ratio of return on assets (ROA) calculated by comparing the net income and total assets owned by the company. The calculation of these variables can be seen in Table 2 .

\section{RESULTS}

This research examined the effect of investment decision on firm value and examined the effect of debt moderation on the investment decision effect on firm value. The variables used in this research were NPR, INV, UTG, UKP, and PRT. The company selected to be the samples in this research were 90 companies. Descriptive statistics of the variables are as follows:

The mean of NPR was 7.3843. It indicated that the mean of market capitalization of manufacturing firms in 2005-2013 in Indonesia was 7.3843 billion. The INV mean was 0.0950. It indicated that the mean of investment increase in fixed assets and working capital in manufacturing company was 0.0950 of the total assets held by the company. The UTG mean was 0.6072 . It indicated that $60.72 \%$ of total assets owned by the company were funded using debt. The UKP mean was 4.2142. It indicated that the mean size of the firm was 3.2455 Billion. The PRT mean was 0.0538. It indicated that the net profit mean earned by the company was $5.38 \%$ of the total assets owned by the company.

Table 4. Determination of Estimation Model between Common Effect and Fixed Effect with Chow Test

\begin{tabular}{lrl}
\hline \multicolumn{1}{c}{ Effect test } & \multicolumn{1}{c}{ Statistic } & Prob. \\
\hline Cross-section F & 21.1872 & 0.0000 \\
Cross-section Chi-square & 1086.0301 & 0.0000 \\
\hline
\end{tabular}

The data in this study were tested using panel data regression. Before performing data analysis, the first step done was to determine the precise estimation model among common effect, fixed effect and random effect. Chow test was 


\section{Debt and Agency Conflict In Indonesian Manufacturing Firms}

Hendra Wijaya, Rr. Puruwita Wardani

done to determine the estimation model between common effect and fixed effect. In Table 4 the significance value of chi-square was $<5 \%$, so fixed effect model was chosen.

Table 5. Determination of Estimation Model between Fixed Effects and Random Effect with Hausmann Test

\begin{tabular}{ccc}
\hline Summary Test & $\begin{array}{c}\text { Chi-Sq. } \\
\text { Statistic }\end{array}$ & Prob. \\
\hline Cross-section Random & 30.0037 & 0.0000 \\
\hline
\end{tabular}

Second step was done to determine the estimation model between fixed effect and random effect. The significance value of cross-section random was $<5 \%$, so that the fixed effect estimation model was selected to be used in this study.

Table 6. Result of Multiple Linear Regression

\begin{tabular}{lcrc}
\hline \multicolumn{1}{c}{ Variable } & Coefficient & \multicolumn{1}{c}{ T-Statistic } & Sig. \\
\hline Constant & -3.0328 & -2.4060 & 0.0164 \\
Investment & 0.5521 & 2.2135 & 0.0271 \\
Debt & -0.4757 & -5.3856 & 0.0000 \\
Invest * Debt & -0.6844 & -2.3483 & 0.0191 \\
Firms Size & 2,5130 & 24.1916 & 0.0000 \\
PRT & 1.2540 & 9.0801 & 0.0000 \\
\hline
\end{tabular}

Hypothesis 1 in this research was that investment decision had a positive effect on firm value. The test results in Table 6 indicated that the investment decision $\left(\beta_{1}=0.5521\right)$ had a positive effect on firm value of the company, and the significance was $\alpha=5 \%$. The test results in table 6 showed that the 1st hypothesis of this study was not rejected. The results of this study were consistent with researches conducted by Fen Hsiao et al. (2011) and Morgado \& Pindado (2003) that found that investment decisions had a positive effect on firm value when investment had not reached the optimum point. In addition, the results of this study were also supported by Del Brio et al. (2003) who found that investment decisions had a positive effect on firm value and was stronger when there was a lucrative investment opportunity.

The second hypothesis in this study was that debt moderated the negative effect of investment decision on firm value. The test results in Table 6 indicated that the interaction between investment decision and debt $\left(\beta_{3}=-0.6844\right)$ had a negative value was significant with $\alpha=5 \%$. Test results in table 6 showed that the second hypothesis of this study was not rejected. The results of this study indicated that the higher debt owned by the company caused a decrease in firm value resulted from investment decision or agency conflicts.

This study used two control variables namely UKP and PRT. The results in Table 6 indicated that UKP coefficient $\left(\beta_{4}=2.5130\right)$ and PRT $\left(\beta_{5}=1.2540\right)$ was significant with $\alpha=1 \%$, which meant that both UKP and PRT variables could become control variables.

\section{DISCUSSION}

\section{Investment Decision and Firm Value}

Based on the research that had been done, the results of this study indicated that investment decision had a positive effect on firm value. Investment decision was a decision that reflected business sustainability and future cash flow. This study showed that investment decision taken at manufacturing companies in Indonesia contributed positively to the increase of firm value that was the shareholder wealth. The results supported the finding that when the investment had not reached the optimum point or there was still a profitable investment, then the investment decision had a positive effect on firm value (Fen Hsiao et al., 2011; Del Brio et al., 2003; Morgado \& Pindado 2003). This study was not supported by research conducted by Chen et al. (2006) who found that investment decisions negatively affected the firm value. 


\section{Jurnal Keuangan dan Perbankan | KEUANGAN}

Vol. 21, No. 2, April 2017: 211-217

Debt Moderated Investment Decision and Firm Value

Based on the research that had been done, the results of this study indicated that investment decision had a positive effect on firm value. Companies in their investment decisions required funding. One form of funding that could be used was debt. This study showed that the increasing use of debt lowered the positive contribution of investment decision to the improvement of firm value. It indicated that the higher use of debt in manufacturing firms in Indonesia where most of the shares were owned by majority shareholders and top managers that were parts of the controlling shareholders might result in expropriation to minority shareholders and harmed to creditors. It was similar to the research conducted by Mahadwartha \& Ismiyanti (2007) that found that increasing use of debt would reduce the company performance, but it was not in line with research conducted by Hassan (2016) that showed that the debt at a certain level could be a mechanism for Agency conflict between majority and minority ownerships.

\section{CONCLUSION AND SUGGESTION}

\section{Conclusion}

The purpose of this study was to examine the influence of investment decision on firm value and tested the moderation of debt on the effect of investment decisions on firm value by using multiple linear regression with moderation. The conclusions that can be taken in this research are: the investment decision has a positive effect on firm value. It shows that investment decision which is the indicator of business continuity can increase firm value. Debt negatively moderates the effect of investment decision on firm value. It indicates that higher corporate debt can reduce the positive effect of investment decision on firm value or agency conflicts.

\section{Suggestion}

Suggestions resulting from research that has been done are (1) for parties that provide funding to the company, they can be more careful. It is due to the higher debt given to the company, the agency conflict that occurs is higher. It certainly becomes a loss for parties that provide funding to the company; (2) for further research, the researcher can do a research on non-manufacturing companies or various industries. It is used to see the effect of debt moderation in non-manufacturing companies or various industries.

\section{REFERENCES}

Ambarish, R., John, K., Williams, J. 1987. Efficient Signalling with Dividends and Investments. The Journal of Finance, XLII (2): 321-343.

Antwi, S., Mills, E, F, E, A., Zhao, X. 2012. Capital structure and firm value: Empirical evidence from Ghana. International Journal of Business and Social Science, 3(22): 103-111.

Chen, C, R., Guo, W., Mande, V. (2006). Corporate Value, Managerial Stockholdings and Investments of Japanese Firms. Journal of International Financial Management and Accounting, 17(1): 29-51.

Chowdury, A., Chowdury, S, P. (2010). Impact of capital structure on firm's value: Evidence from Bangladesh. Business and Economic Horizons, 3(3): 111-122.

Claessens, S., Djankov, S., Lang, L, H, P. (2000). The separation of ownership and control in east asian corporations. Journal of Financial Economics, 58(1-2): $81-112$.

Del Brio, E., De Miguel, A., Pindado, J. (2003). Investment and Firm Value: An Analysis using Panel Data. Applied Financial Economics, 13(12):913-923.

Fenandar, G, I. \& Raharja, S. 2012. Pengaruh Keputusan Investasi, Keputusan Pendanaan, dan Kebijakan Dividen terhadap Nilai Perusahaan. Diponegoro Journal of Accounting, 1(2): 1-10.

Fen Hsiao, F., Ying Hsu, C., An Li, C., Chi Hsu, Ai. 2011. The Relationship among Managerial Sentiment, Corporate Investment, and Firm Value: Evidence 


\section{Debt and Agency Conflict In Indonesian Manufacturing Firms}

Hendra Wijaya, Rr. Puruwita Wardani

from Taiwan. Emerging Markets Finance \& Trade, 47(2): 99-111.

Fitri, N., Irianto, G., \& Mardiati, E. 2017. The Effect of Ownership Structure on the Expropriation Risk. International Business Management, 11(2): 392-396.

Gitman, L,J. \& Zutter, C, J. 2012. Principles of Managerial Finance ( $13^{\text {th }}$ edition). Published by Prentice Hall.

Hassan, H. 2016. Debt and Ownership Concentration as Corporate Governance Mechanisms: Evidence from the Large Australian Firms. International Business Management, 10(17): 3921-3928.

Jensen, M, C. 1986. Agency Costs of Free Cash Flow, Corporate Finance, and Takeovers. American Economic Review, 76(2):323-329.

Kim, W, S., Lyn, E., Jun Park, T., Zychowics, E. 2005. The Wealth Effects of Capital Investment Decisions: An Empirical Comparison of Korean Chaebol and Non-Chaebol Firms. Journal of Business Finance and Accounting, 32(5-6): 945-971.

Mahadwartha, P. A. \& Ismiyanti, F. 2007. Does Debt Affect Firm Financial Performance? The Role of Debt on Corporate Governance in Indonesia. Prosiding. Simposium Nasional Akuntansi X.

Manawaduge, A., Zoysa, A, D, Chowdury, K., Chandarakumara, A. 2011. Capital Structure and Firm Performance in Emerging Economies: An Empirical Analysis of Sri Lanka Firms. Corporate Ownership \& Control, 8(4): 253-263.
Morgado, A. \& Pindado, J. 2003. The Underinvestment and Overinvestment Hypotheses: An Analysis using Panel Data. European Financial Management, 9(2): 163-177.

Myers, S.C. 1977. Determinants of Corporate Borrowing. Journal of Financial Economics, 5(2):147-175.

Ruan, W., Tian, G., Ma, S. 2011. Managerial Ownership, Capital Structure, and Firm Value: Evidence From China's Civilian-Run Firms. Australasian Accounting, Business, and Finance Journal, 5(3):73-92.

Salim, M., \& Yadav, M.S. 2012. Capital Structure and Firm Performance: Evidence from Malaysian Listed Companies. Procedia - Social and Behavioral Sciences, 65(2012): 156-166.

Villalonga, B. \& Amit, R. 2006. How Do Family Ownership, Control And Management Affect Firm Value? Journal of Financial Economics, 80(2): 385-417.

Yuliana, D., Anwar, M., Layyinaturrobaniyah. 2016. Pengaruh Struktur Modal, Biaya Modal Ekuitas, dan Struktur Kepemilikan terhadap Nilai Perusahaan: Studi Empiris pada Sektor Aneka Industry di Bursa Efek Indonesia. Proceeding, The $2^{\text {nd }}$ Indonesian Finance Association International Conference 2016. 